\title{
高齢者見守りのための音情報を用いた転倒識別に関する研究
}

\author{
中山 仁史 ${ }^{* 1}$, 石光 俊介 ${ }^{* 1}$, 中西 良太 ${ }^{* 2}$, 坂野 史歩 ${ }^{* 2}$, 空田 卓也*3, 前田 夕貴 ${ }^{* 3}$
}

\section{A study of falling discrimination using sound information for watching elderly people}

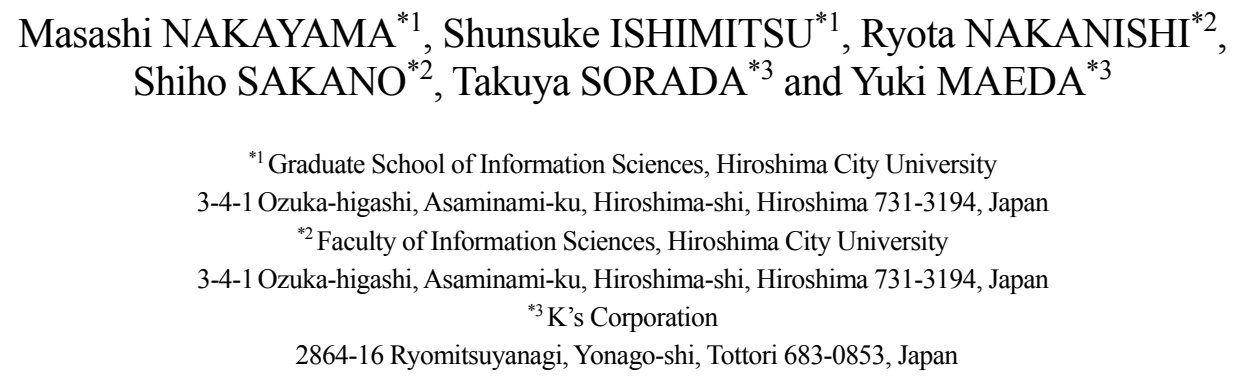

Received 3 April 2016

\begin{abstract}
Recently, we have faced on the problem such as increasing elderly people who have occurred accidents including solitary death and falling and so on at their houses. To deal with these problems, many researchers and companies are proposing and releasing the systems monitored by sensors for keeping them safety. However, conventional systems using sensors including cameras and microphones give little privacy. In order to solve the problems, we proposed and discussed the falling discrimination using sound information for watching elderly people. Proposed system expects the falling discriminations using acoustic features extracted from sound. For discrimination accurately, we focused on Spectrum gravity between subjects/things and flooring styles. The feature characterized and modeled as Spectrum ratio of delta power as dynamic parameter. Finally, experiments of two-class discriminations using feature parameters achieved to $96.83 \%$ with dataset of unspecific conditions.
\end{abstract}

Key words : Falling discrimination, Sound, Zero corss, Delta power, SVM, K-NN

\section{1. はじめに}

\section{$1 \cdot 1$ 研究背景}

我が国は少子高齢化や核家族化にともない, 高齢者における人口割合が増加傾向にある(総務省統計局, 2015). これは諸外国と比較して最も高い水準であり，増加する独居老人や老々夫婦の安心や安全の確保が求められてい る（The World Bank, 2015）。独居老人の転倒事故は，早期発見や初動対応が難しく死につながるケースも多い. しかしながら，少子高齢化にともない呼応される人材の確保が難しく, 24 時間体制の介護施設でも必ずしも十分 な対応ができるとはいえない.このような背景から，カメラを用いて転倒などを検知する技術（土井他, 2006）（ラ ムロック，2011），加速度センサを用いてヒトの歩行や転倒を検知する技術（品川他，1999），加速度センサを用 いてドアの開閉や異常が生じた場所を検知する技術（Bendary et al., 2013）（Libero，2008）など，様々な高齢者見 守り技術が提案されるようになってきた．ところが，多くの技術が提案・実現される一方で，プライバシーに対 する不安や精神的負担，コストの増加，また生理現象や機器利用情報による間接的な確認など，新たな課題が浮 き彫りとなってきた。このような課題から，音や振動などの音情報を用いた見守り技術が提案されるようになっ てきた．この例として，音の高さに注目したメル周波数ケプストラム係数である MFCC(Mel Frequency Cepstrum

\footnotetext{
No.16-00151 [DOI:10.1299/transjsme.16-00151], J-STAGE Advance Publication date: 30 November, 2016

*1 正員, 広島市立大学 大学院情報科学研究科（干731-3194 広島県広島市安佐南区大塚東 3-4-1）

*2 広島市立大学 情報科学部

*3（株）ケイズ（干683-0853 鳥取県米子市両三柳 2864-16

E-mail of corresponding author: masashi@hiroshima-cu.ac.jp
} 
Nakayama, Ishimitsu, Nakanishi, Sakano, Sorada and Maeda,

Transactions of the JSME (in Japanese), Vol.82, No.844 (2016)

Coefficient)を用いた技術（Khan et al., 2015）（西他，2014），複数マイクロフォンを用いたマイクロフォンアレイ による技術（池田，2013）などが提案されている．従来法では転倒音と非転倒音を識別するためのモデルやテン プレート，複数のマイクロフォン，加速度ピックアップ，被験者また設置環境など対象に応じたパラメータ設定 やチューニングなどの課題もある.

\section{$1 \cdot 2$ 音情報を用いた転倒識別}

著者らは従来法と同様にマイクロフォンで採取した音情報を用いた転倒識別を試みるが，音情報は画像情報と 同様に会話内容の流出といったプライバシー問題が懸念される. しかしながら, 数フレーム程度の音情報では発 声時の基本周波数や音素・音節などのサブワード情報などしか得ることが出来ないため, フレーム単位で処理・ 革却することでプライバシ一の担保が期待できる．また，マイクロフォンはあらゆる携帯端末の I/O として付属 されており, 本研究成果を携帯電話や PDA などへ簡単に導入また実装寸ることができる. これらに加え, 著者 らの方法では転倒識別で必要なモデルやテンプレートにおけるパラメータの事前推定を必要としない特徵も有し ている. 一般的に, パターン認識を行うためにはモデルやテンプレート内に存在するクラスや境界情報が求めら れる. しかしながら，高齢者を対象とした見守り技術では被験者や設置環境毎に応じたモデルやパラメータの再 推定を行うことは現実的ではない. そこで, 著者らは被験者や落下物また室内条件に頑健な音響特徴量に注目し, 被験者, 床面条件などに依存しない不特定環境条件下での転倒識別を試みている（石光他, 2016）。実利用を考慮 すると必ずしも静寂環境下で転倒音及び非転倒音が得られるとは限られず，日常生活において生じる雑音や会話 音声などと転倒音を分離する課題がある.このような問題は雑音環境下で得られた音声に対してブラインド信号 処理で音源分離を行うことができる．また，実利用を考慮すると転倒音と他の生活雑音などのオーバーラップも 懸念される，本論文では転倒音及び非転倒音の音響的特徵を捉えて識別を試みるもので，理想的な静寂環境下で 採取した音源を対象とした転倒音識別として検討を行う.

\section{$1 \cdot 3$ 本論文の構成}

本論文では転倒音及び非転倒音の音響的特徵を明らかにし，得られた音響的特徵に注目した音響特徵量の提案 と識別を試みる. そこでまず, 時間周波数分析を用いて転倒音及び非転倒音の音響的特徵ついて議論する. 次に, 転倒音に含まれる特徵に注目した音響特徵量ついて議論する. 最後に, 静的な音響特徵量を動的特徵に拡張し, 不特定環境条件下での 2 クラス識別で識別性能を定量的に明らかにする.

\section{2. 転倒音及び非転倒音の時間周波数分析}

転倒識別は音から抽出した音響的特徴を用いて行う。そこで，転倒音及び非転倒音のデータセットを構築し， これを用いて転倒音及び非転倒音の音響的特徵を明らかにする.

\section{$2 \cdot 1$ 転倒音及び非転倒音のデータセット 1 （Dataset 1）}

転倒音及び非転倒音の音響的特徵を確認寸るために，転倒音及び非転倒音からなるデータセット 1（Dataset 1) を構築した，データセット 1 は，表 1 の信号収録装置を用いて和室内で収録した．音は計測用マイクフォンを用 いて, サンプリング周波数 $16,384 \mathrm{~Hz}$, 量子化サイズ 16 bit で収録した. 被験者は 20 歳から 24 歳までの健常者 14 名（男性 11 名及び女性 3 名, 身長約 150 180cm, 体重約 45 80kg) とし, 転倒パターン 4 種（左側倒, 右側倒, 前方躓き, 前方膝崩れ）の転倒を行った。これは被験者の安全を考慮して後頭部の打撃の恐れのある後方の転倒 を除き，前方の 2 種類及び左右の転倒を用いたことによるものである. 前方の転倒は胴体また下肢からの転倒が 考えられるため, 前方躓き及び前方膝崩れの 2 種類として行った. また非転倒音として, 日常生活で身近な物 8 種（ポロシャツにハンガー, 携帯電話, ペン, コップ, タンブラー, 本, ペットボトル, ティッシュ箱）の落下 音と家具 1 種（机）の移動音を収録した. 音を生じさせる方法は落下 2 種（机上の $100 \mathrm{~cm} ）$ と移動 1 種（3 秒程 度の引きずり）とした．転倒音は被験者 14 名 $\times$ 転倒パターン 4 種=計 56 サンプル, 非転倒音は物体 8 種 $\times$ 落下 2 種 $\times 4$ トライアルと机 1 種 $\times$ 移動 1 種 $\times 4$ トライアル=計 68 サンプルとなった. このとき, 身近な物や家具はヒ トと比較して小さいものを用いることにした．これはヒトの転倒時と同様またそれ以上の音が生じるような大型 
の家具や家電はそもそも生じる転倒音が大きなため,これらは転倒時に生じるパワーで識別できると推察できる. 大型の家具や家電が転倒した際は転倒及び非転倒に関係無く対応が必要なため，転倒音識別としての対象からは 除外することとした．なお，このデータセット 1 は室内と床面条件を和室及び畳で固定のため，特定環境条件下 のデータセットとして扱うことにする.

Table 1 Equipment for signal recording.

\begin{tabular}{c|c}
\hline \hline Equipment & Model \\
\hline Microphone & ONOSOKKI MI-1431 \\
\hline Pre-amplifier & ONOSOKKI MI-3310 \\
\hline Recorder & B\&K LAN-XI 3050-B-060 \\
\hline
\end{tabular}

\section{$2 \cdot 2$ パワーの極值数}

転倒音及び非転倒音はヒトの聴感で違いが確認できるため, 音響的特徵の差異があると推察できる. そこで, 転倒時及び非転倒時に生じるパワーの極值数に注目することにした.

図 1 に転倒音及び非転倒音のパワーの極值数を示す。転倒音と非転倒音を比較して，転倒音で複数回，非転倒 音で 1 回もしくは 2 回程度の極值が確認できる. 特に, 転倒音においてより多くの極值数が確認できた。ボール ではヒトと同様に複数回の極值数が確認されたが，自由落下と地面による反発の繰返しで規則的なパターンを有 する傾向がある. 以上のことから, ボールなどではヒトと同様に複数回の極值数が観測される傾向があるものの, パワーの極值数は転倒識別で有用な音響特徴量の一つとして有用であるといえる.

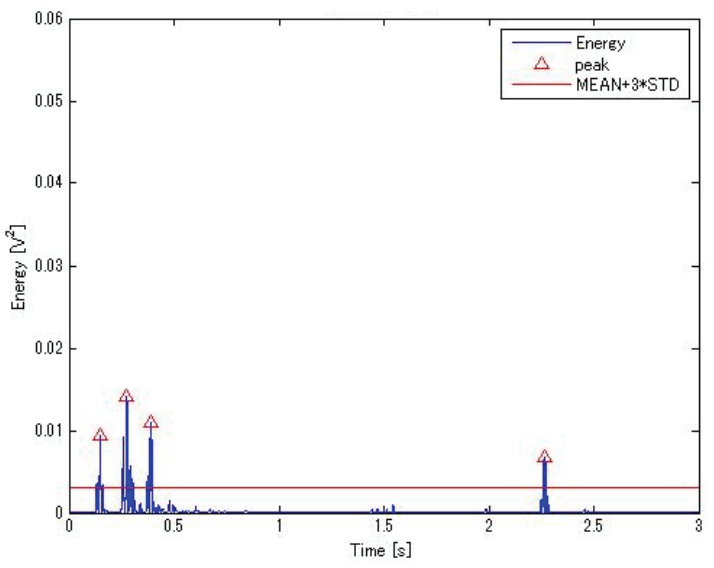

(a) Falling (Subject).

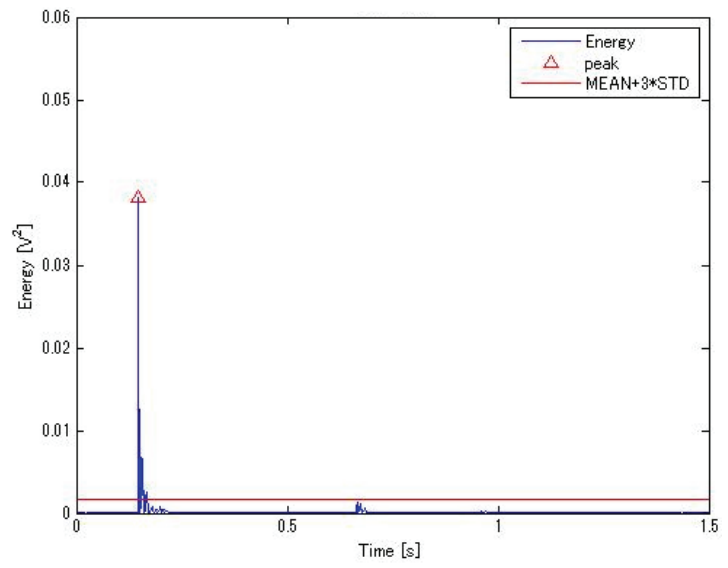

(b) Falling (Ball).

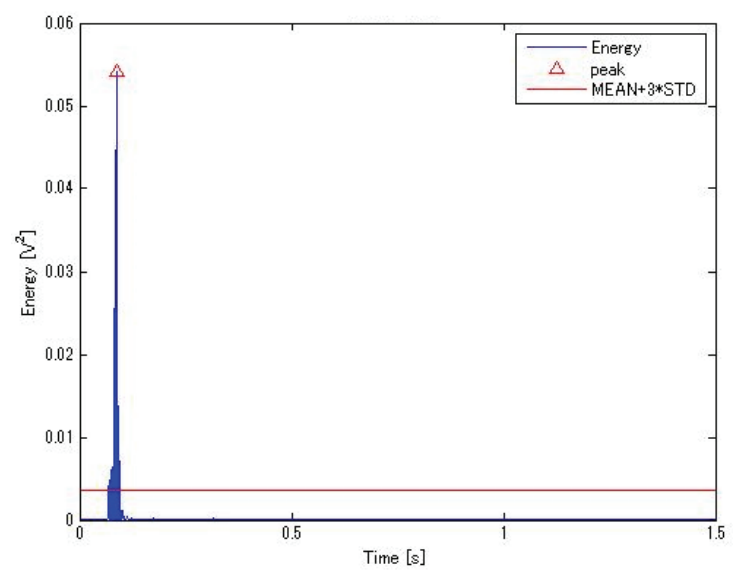

(c) Falling (Book).

Fig. 1 Power envelope peaking measured by microphone. 


\section{$2 \cdot 3$ 時間周波数分析}

転倒音及び非転倒音はヒトまた落下物と床面との関係で生じる周波数の違いが観察できる，そこで，非転倒音 (本) を対象にスペクトログラムやウェーブレット解析などの時間周波数解析で音響的特徴を明らかにする(金井, 1999). 本はヒトと比較して極值数が少なく鋭いインパルス信号となるため, 本で時間周波数解析することで本以 外でも同様に解析できることが確認できる，一般的に，非定常音は時々刻々と変化するため，空関数などで切り 出した短時間幅のフレーム単位で時間周波数解析が行われる. 代表的な解析方法として，以下の式（1）で示すよ うなフーリエ変換を用いたスペクトログラム $Y(t, f)$ が用いられる.

$$
Y(t, f)=\int_{-\infty}^{+\infty} y(\tau) w^{*}(\tau-t) e^{-j 2 \pi f \tau} d \tau
$$

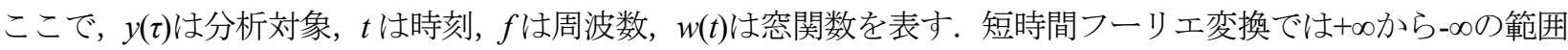
の時間信号 $y(t)$ を有限長 $T_{0}$ の空関数 $w(t)$ でフレーム化し，その区間が周期的に継続しているものとしてフーリエ 級数展開を行う方法である．ところが，短時間フーリエ変換では空関数の長さは全て一定の解析条件で用いるた め, 解析対象の周波数によっては不適切な結果となる恐れがある. そこで, 以下の式 (2) で示すような空関数 $w(t)$ と長さ $T_{0}$ に自由度を持たせたウェーブレット変換 $W T(t, a)$ が用いられる.

$$
W T(t, a)=\frac{1}{\sqrt{a}} \int_{-\infty}^{+\infty} y(\tau) g^{*}\left(\frac{\tau-t}{a}\right) d \tau
$$

ここで, $\mathrm{y}(\tau)$ は分析対象， $t$ は時刻， $g^{*}(t)$ はウェーブレット変換における基底関数， $a$ はスケールパラメータを 表す．このとき，WT(t,a)を $|W T(t, a)|^{2}$ とすることでスキャログラムとなる. さらに，スケールパラメータを周波数 と置き換えることで，以下の式（3）で示すような周波数軸に対応したウェーブレット変換 $W T(t, a)$ が得られる.

$$
W T(t, f)=\sqrt{\frac{f}{f_{0}}} \int_{-\infty}^{+\infty} y(\tau) g^{*}\left(\frac{f}{f_{0}}(\tau-t)\right) d \tau
$$

本研究ではウェーブレット変換の基底関数として Morlet ウェーブレットを用いることにした. Morlet ウェーブ レットは包絡をガウス曲線で，キャリアを複素正弦波で表現した関数である（Grossmann and Morlet, 1984）．以下 の式 (4) に, Morlet ウェーブレット $g_{M}(t)$ を示す.

$$
g_{M}(t)=\exp \left(-\frac{t^{2}}{2}\right) \exp \left(j \omega_{0} t\right)
$$

図 2 に非転倒音（本）落下時の時間周波数解析の結果を示寸．結果は最上段から波形，スペクトログラム，ス キャログラムの結果を示している，スペクトログラムでは均等スケールで解析しているが，スキャログラムでは 高域スケールに従って高い時間分解能が得られる，転倒音の性質として，非定常過渡音であること，転倒前後の 状態に対して不連続であることがあげられる，解析結果からも確認できるように，ウェーブレット変換では上に 凸のコーン状の分布として解析され，この凸の状態により不連続点でごの時点で異変が起きているのかがウェー ブレットでは観測できる，よって，不連続点前後の特徵から転倒音解析をすればよく，その意味でも定常性の前 提に基づくスペクトログラムよりも適切であるといえる. 
よって，ウェーブレット解析を用いることで転倒時に生じるスペクトル重心をより詳細に捉えることができ， 転倒及び非転倒音の音響的特徵を確認することができる，スペクトル重心はスペクトル形状を表現することがで き，心理音響的にはブライトネスとして表現される（Grey, J. M. and Gordon, J. W., 1978）。そこで，本研究ではウ エーブレットを用いて転倒音及び非転倒音のスペクトル重心の音響的特徵を確認する.
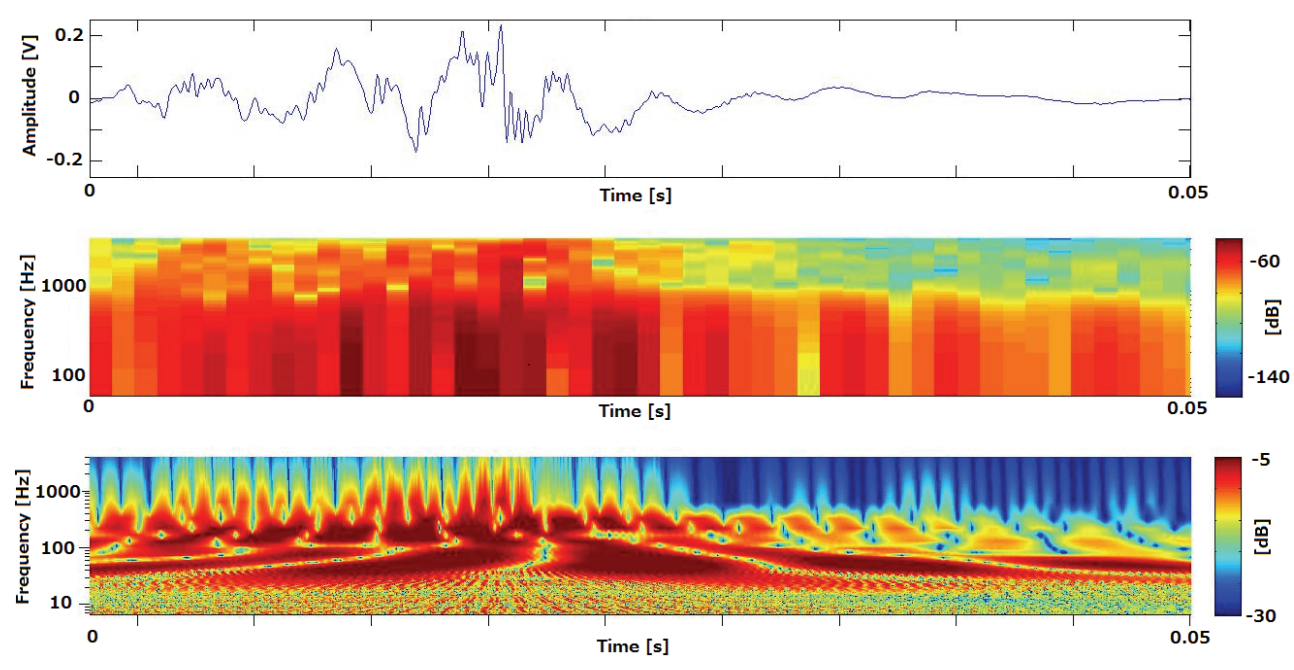

Fig. 2 Time-frequency analysis of falling (Book).

\section{3. 転倒音及び非転倒音識別のための音響特徴解析}

転倒音及び非転倒音の時間周波数解析の方法としてウェーブレット解析を用いることが適切であることを確認 した，そこで，ウェーブレット解析を用いて信号データベースにおける転倒音及び非転倒音の音響的特徵を明ら かにする.

\section{$3 \cdot 1$ ウェーブレット解析を用いた音響特徴解析}

図 3 にデータセット 1 の転倒音及び非転倒音のウェーブレット解析の結果を示す.図 3 より, ヒトでは約 $330 \mathrm{~Hz}$, ボールでは約 $650 \mathrm{~Hz}$ ，本では約 $220 \mathrm{~Hz}$ においてスペクトルの重心が確認できた．加えて，図 4 に床面の違いによ る転倒音のウェーブレット解析，図 5 に転倒パターンの違いによる転倒音のウェーブレット解析を示寸．図 4 及 び図 5 の各結果より, 異なる床面また転倒パターンともに約 $330 \mathrm{~Hz}$ のスペクトル重心が確認でき, 異なる条件で あったとしても転倒識別が期待できる.
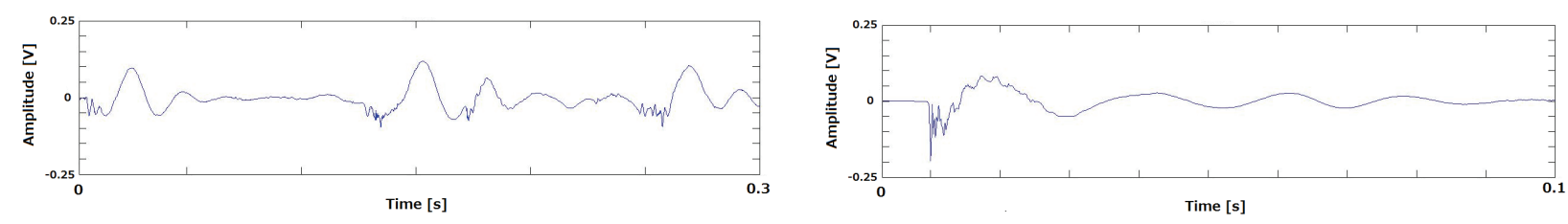

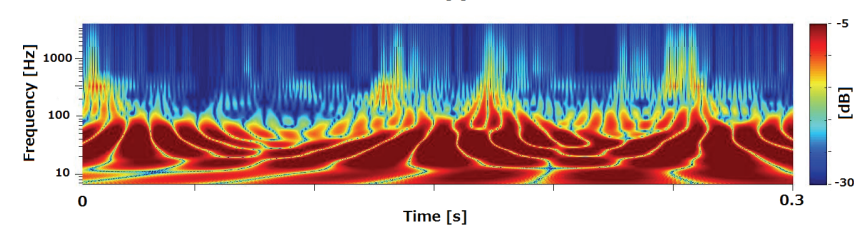

(a) Falling (Subject).

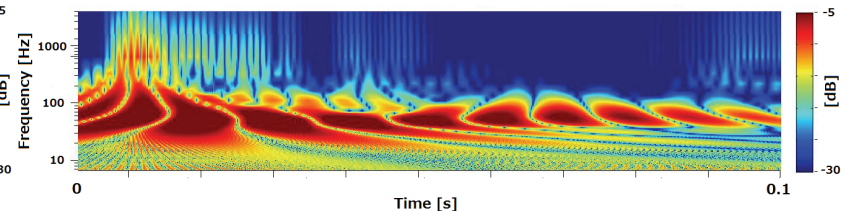

(b) Falling (Ball). 
Nakayama, Ishimitsu, Nakanishi, Sakano, Sorada and Maeda,

Transactions of the JSME (in Japanese), Vol.82, No.844 (2016)
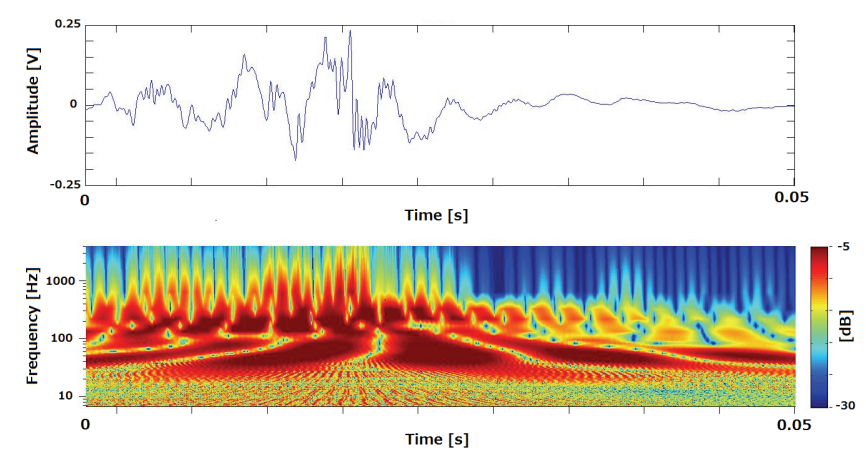

(c) Falling (Book).

Fig. 3 Wavelet analysis of falling and not falling (Book).
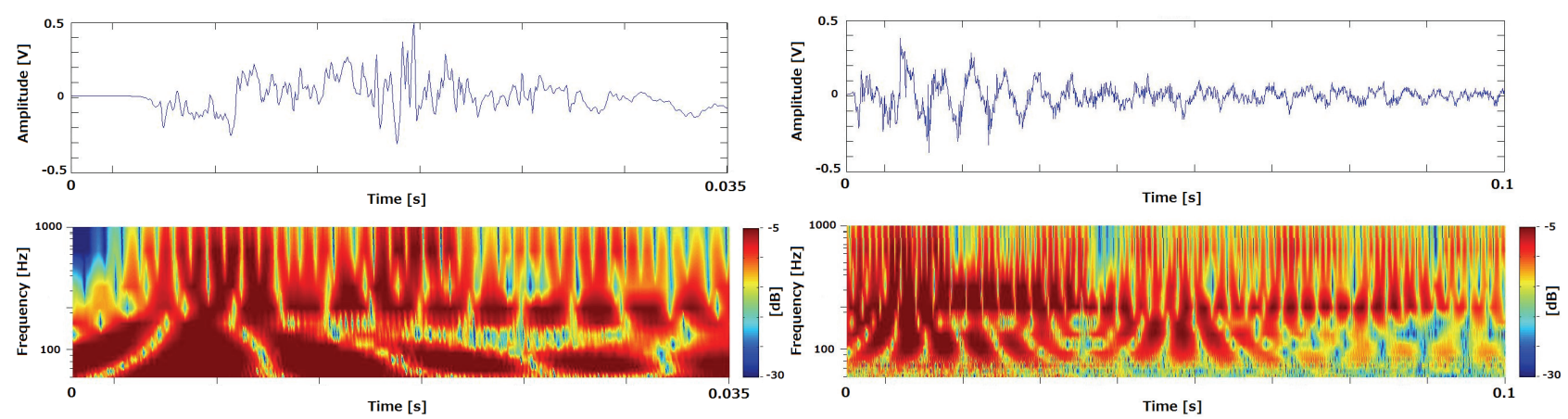

(a) Japanese style carpet Tatami at Japanese style room.

(b) Concrete flooring at Western style room.
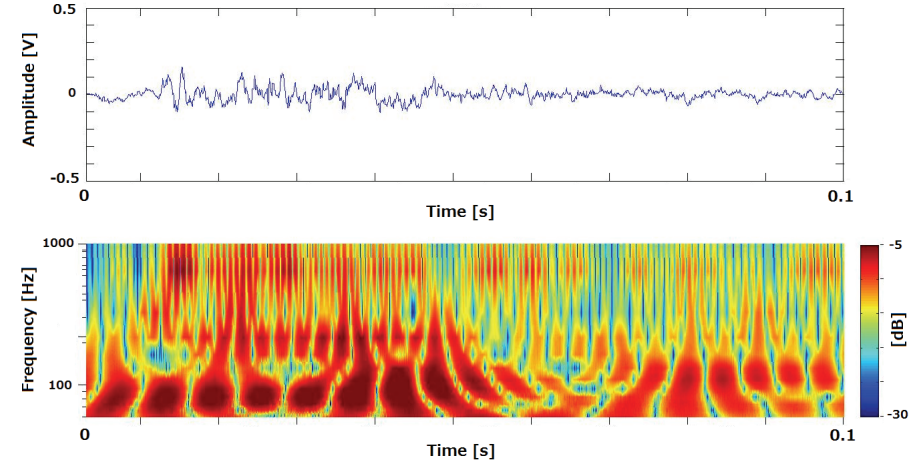

(c) Wooden flooring at Gym.

Fig. 4 Wavelet analysis of differences between rooms and flooring styles.
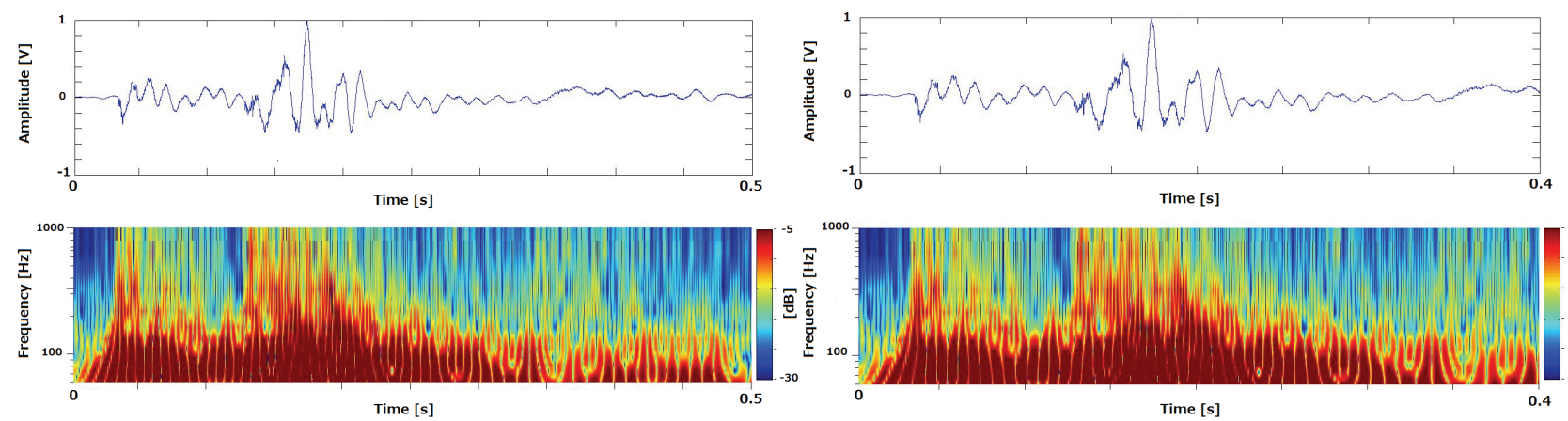

(a) Left side.

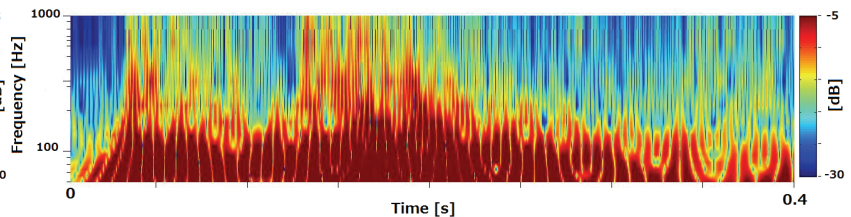

(b) Right side. 

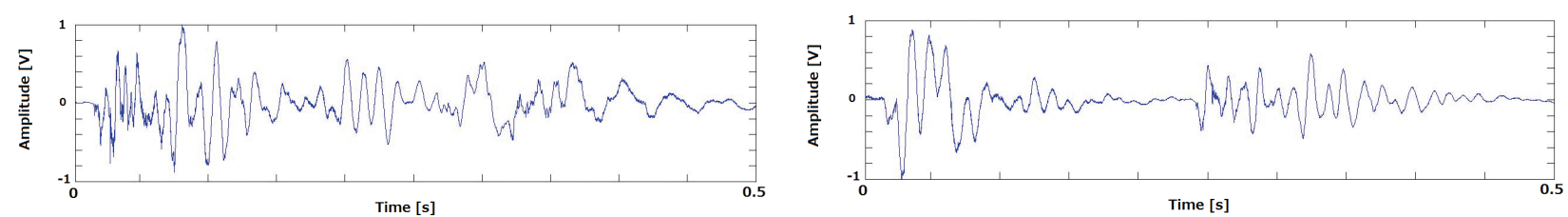

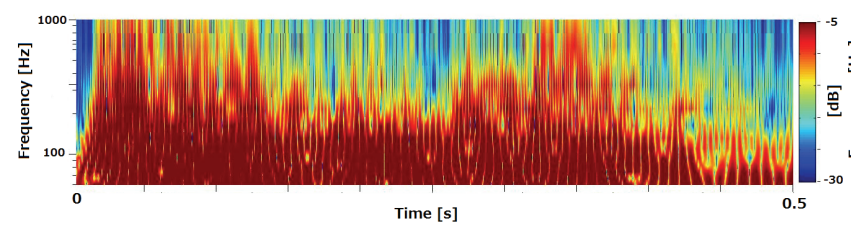

(c) Stumbling.

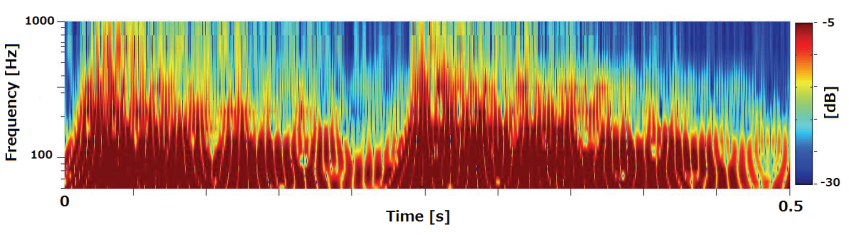

(d) Knee collapse.

Fig. 5 Wavelet analysis of differences at falling styles.

\section{$3 \cdot 2$ スペクトル重心のパラメータ化}

パワーの極值数はスカラであるため, 得られた極值数を識別パラメータとして直接用いることができる.一方, ウェーブレット解析で得られるスペクトル重心は時系列のベクトルのため, 時間軸方向に次元圧縮するなどし,

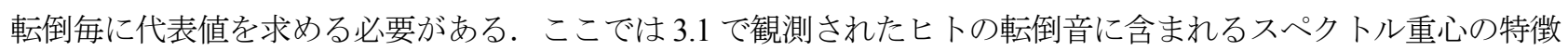
を一つの基準とし，中心周波数 $330 \mathrm{~Hz}$ 及びバンド幅 $30 \mathrm{~Hz}$ のバンドバスフィルタで処理した信号に対して零交差 数を用いて音響特徴量とすることにした (Gouyon et al., 2000). 零交差数とは背景信号の零を基準に正負の反転が 生じたかをカウントしたスカラであり, 転倒音として特徴が確認された $330 \mathrm{~Hz}$ を中心に定量的な特徵量化を行う ことができる.

図 6 にパワーの極值数, 図 7 に零交差数の結果について示す. 図 6 より, 本におけるパワーの極值数が 1 回で あるが，ヒトにおけるパワーの極值数にばらつきがあることが確認できる．しかしながら， ヒトと本の標準偏差 の分布に重なりが確認できないことから，転倒識別における音響特徵量として有用であるといえる．一方で，図 7(a)の各零交差数は標準偏差の分布に重なりがあるため, 直接用いたとしても高い識別性能を得ることが難しい. そこで, 転倒音のスペクトル重心に注目した $330 \mathrm{~Hz}$ のバンドパスフィルタを用いて, スペクトル重心付近の情報 に絞り音響的特徵を捉えることにした。 これにより, 図 7(b)では標準偏差のオーバーラップが無く, 各分布の重 なりが少ないことが確認できた，以上のことから，フィルタリング後の零交差数を用いることで，より頑健な音 響特徴量の表現が期待できるといえる.

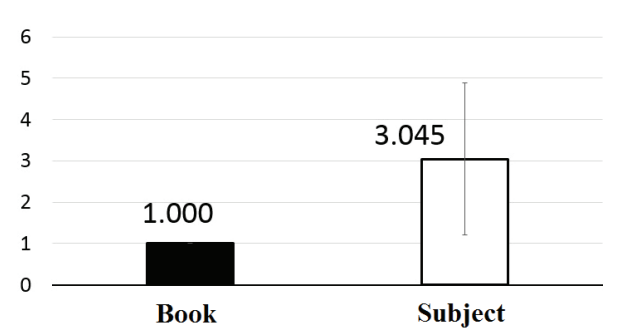

Fig. 6 Peaking counts of power envelope.

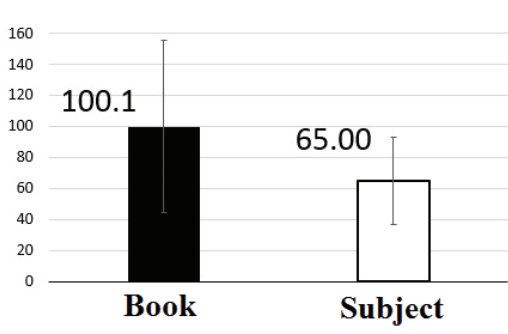

(a) Without filtering.

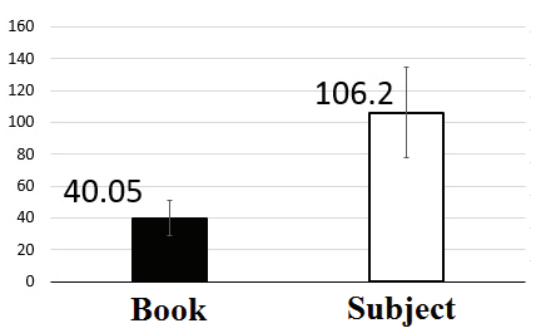

(b) With filtering.

Fig. 7 Counts of zero-cross.

\section{4. 不特定環境条件下でも頑健な音響特徵量を用いた転倒識別}

音情報を用いた理想的な転倒識別は，テンプレートやモデル推定を要しない不特定環境条件下での転倒識別で ある．そこで，より頑健な転倒識別を行うためにパワーを動的特徵に拡張した音響特徵量を提案し，これを用い た転倒識別で識別性能を定量的に示す. 


\section{$4 \cdot 1$ 転倒音及び非転倒音のデータセット 2（Dataset 2)}

不特定環境条件下での検討を行うために，転倒音及び非転倒音のデータセット2（Dataset 2）を構築した. 転倒 音及び非転倒音は表 1 の信号収録機器を用いて, サンプリング周波数 $16,384 \mathrm{~Hz}$, 量子化サイズ 16 bit で収録した. 被験者は 22 歳から 34 歳までの健常者 4 名（男性 3 名及び女性 1 名, 身長約 150 175 cm, 体重約 45 98kg）とし, 床面条件は 3 条件 (畳, フローリング, カーペット), 転倒パターンは 2.1 の 4 種とした. 物体落下音は 3 種 (本, ペン，携帯電話）をそれぞれ 2 回落下させた。このとき，携帯電話の落下は衝撃が鋭くフローリングもしくは携 帯電話が破損する恐れがあったため，畳とカーペットのみを対象とした．以上のことから，転倒音は被験者 4 名 $\times$ 床面条件 3 種類 $\times$ 転倒パターン 4 種=計 48 サンプル, 非転倒音は物体 3 種 $\times$ 床面条件 3 種類 $\times 2$ トライアルから携 帯電話のフローリング条件の 2 トライアルを引いた=計 16 サンプルとなった. なお，このデータセット 2 は室内 と床面条件を複数含む条件となるため，不特定環境条件下のデータセットとして扱う．

\section{$4 \cdot 2 \Delta P o w$ を用いたスペクトル重心のパラメータ化}

データセット 2 の転倒音及び物体落下音を用いてパワーと同様にスペクトル重心が利用できるかの確認を行う. 転倒音や物体落下音が生じるとき, 物体の質量, 初期加速度, 接触面また接触角度などの影響を受ける. 特にパ ワーの大きさは様々な要因で変化するため, あらかじめ推定したモデルやパターン内のスケールと異なるため比 較が難しい. そこで, 影響の受けやすいパワーであるPowの変化分もしくは速度分である動的特徵の $\Delta P o w$ を導 入することにした（Furui, 1986）。これにより，転倒者の体格差や落下時の各条件などによって生じるパワーの差 を疑似的に正規化することができるため, 転倒識別のための頑健な特徽量となることが期待できる. 以下の式 (5) に $\Delta$ Pow の計算式を示寸.

$$
\Delta \operatorname{Pow}(t)=\lim _{\Delta t \rightarrow 0} \frac{\operatorname{Pow}(t+\Delta t)-\operatorname{Pow}(t)}{\Delta t}
$$

図 8 に 4 Pow における転倒音及び非転倒音の時間周波数解析の結果を示寸.図 8(a), (b)及び(c)に異なる被験者, 転倒パターンまた床面条件毎の転倒音に対する周波数特性, 図 8(d)及び $(\mathrm{e})$ に異なる落下物や床面条件における非 転倒音の周波数特性を示寸. 各結果から確認できるように, 被験者, 転倒パターンまた床面条件において $200 \mathrm{~Hz}$ から $300 \mathrm{~Hz}$ 付近にスペクトル重心が確認できる. 一方で, 図 8(d)及び(e)では, $300 \mathrm{~Hz}$ 以降にスペクトル重心が 確認できる．これは，単純なパワーと比較してスペクトル重心の周波数に差はあったものの，APowを用いるこ とでこれらの差を疑似的に正規化し，頑健な転倒識別が可能な音響特徵量が得られたことを意味する．これらの 結果より, 先に示したパワーと同様に転倒時のスペクトル重心に注目することで転倒識別が期待できるといえる.

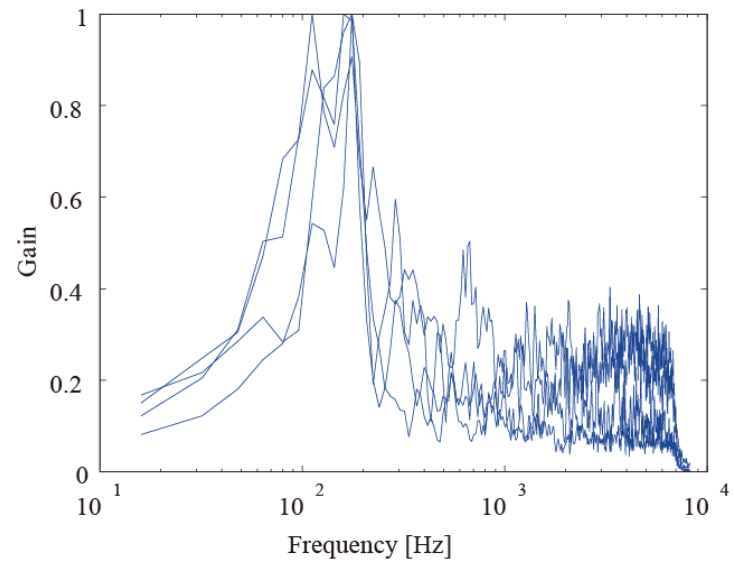

(a) Falling (Four subjects).

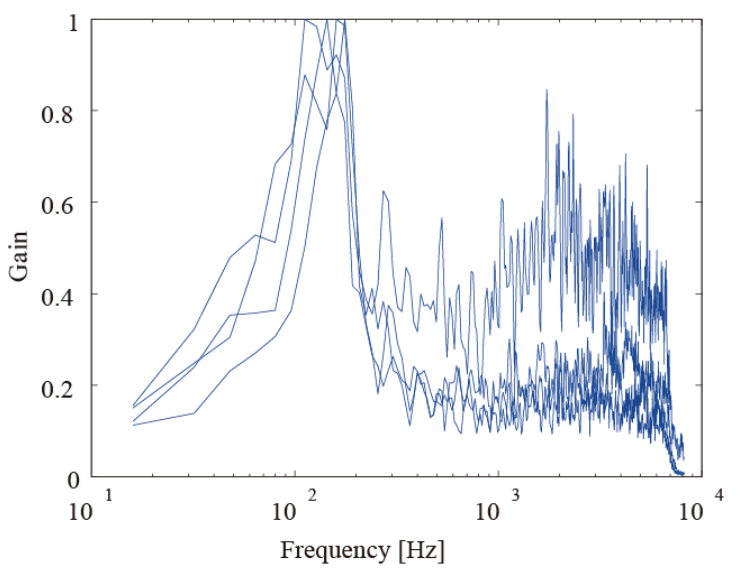

(b) Falling (Four falling styles). 


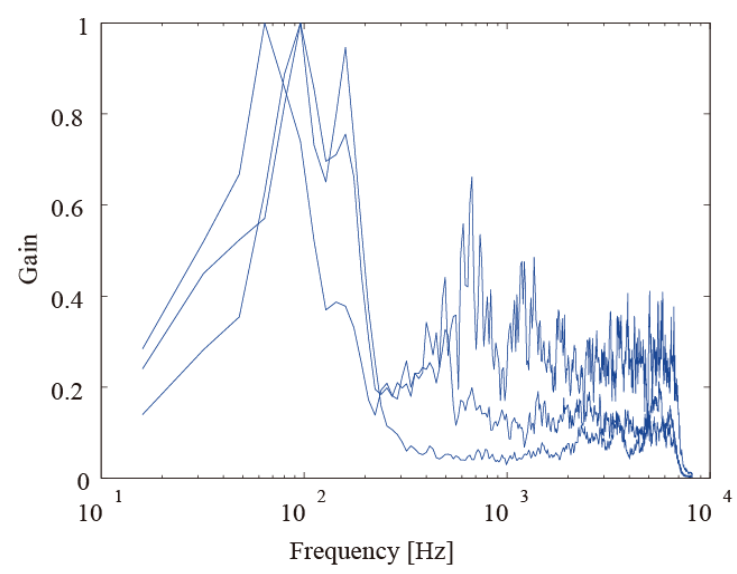

(c) Falling (Three flooring styles).

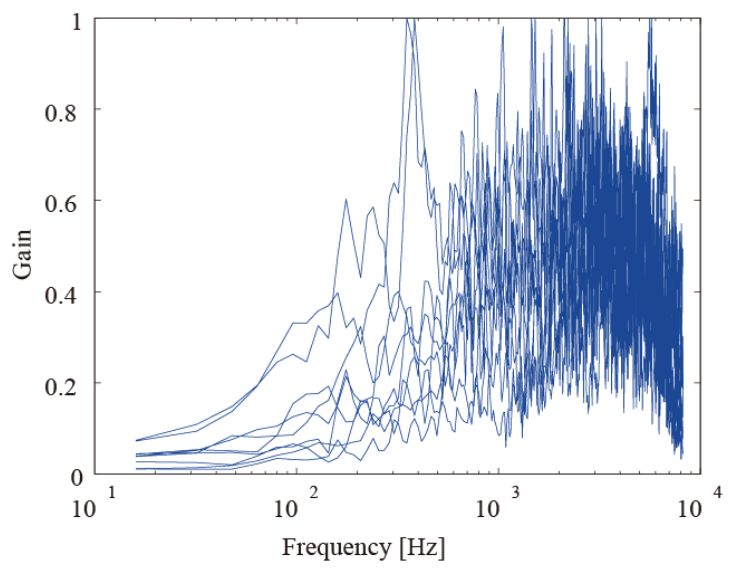

(d) Falling (Nine things).

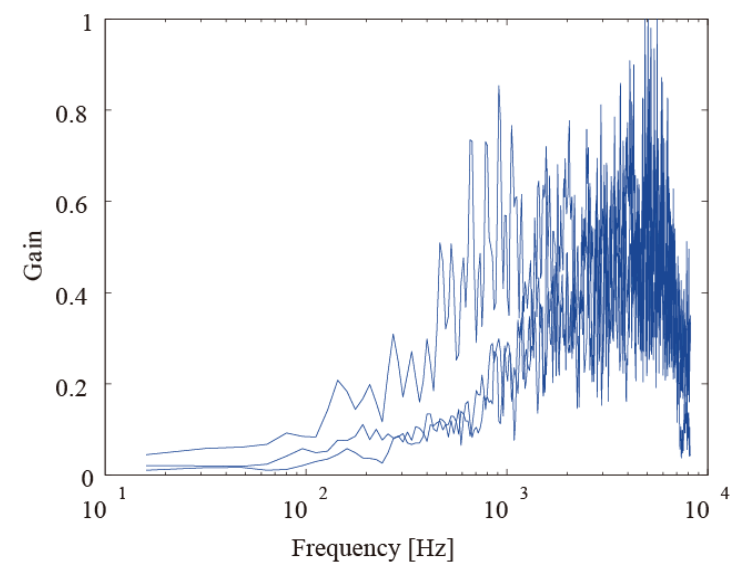

(e) Falling (Pen at Three flooring styles).

Fig. 8 Frequency characteristics of falling and not falling at delta power.

\section{$4 \cdot 3$ 転倒識別のための音響特徴量 $R_{\Delta P O w}$}

パワーは被験者や転倒条件において得られる不安定なパラメータであるため, 被験者, 落下物, 転倒パターン などの条件の変動に頑健な転倒識別のための音響特徵量 $R_{\Delta P o w}$ を提案することにした． $R_{\triangle P o w}$ は $\triangle P$ Pow を時間周波 数解析して得られた特徵に注目し, 転倒音と非転倒音で特徵差が確認できる高域周波数成分と低域周波数成分の 比としたパラメータである（石光他，2016）。

APow は転倒時に生じるパワーの変化分とすることで, 転倒時に生じるパワーの大きさの影響を低減して比較 することができる. $\Delta$ 特徵量は音声認識で広く用いられており， $\Delta P$ ow を転倒毎に正規化することや数フレーム前 後の回帰線として表現することでより頑健なパラメータ表現が期待できる（Furui, 1986）。本研究では，転倒識別 における $\Delta$ 特徴量の最初の検討として単純な $\Delta$ を用いることにする. 以下の式（6）及び図 9 に， $R_{\Delta P o w}$ を求める 各式また手続きを示す，なお，転倒音及び非転倒音の境界を任意の閾值として設定することで，転倒音及び非転 倒音に限らず様々な識別に利用することができる.

$$
R_{\Delta \text { Pow }}=\frac{\overline{H P F_{\text {Threthold }}(F F T(\triangle P o w))}}{\overline{L P F_{\text {Threthold }}(F F T(\triangle P o w))}}
$$


Nakayama, Ishimitsu, Nakanishi, Sakano, Sorada and Maeda,

Transactions of the JSME (in Japanese), Vol.82, No.844 (2016)

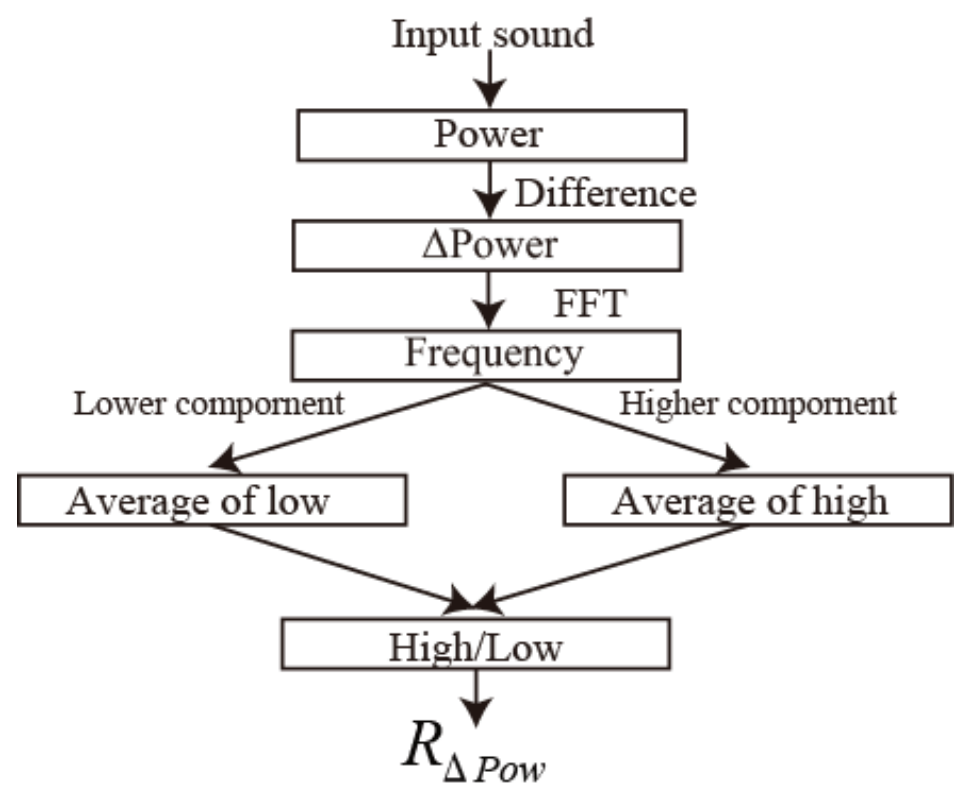

Fig.9 Calculation procedure of proposed acoustic feature $R_{\Delta}$ Pow.

\section{$4 \cdot 4$ パワー及び $R_{\Delta P o w}$ を用いた 2 クラス識別による転倒識別}

零交差数とパワーもしくは $R_{\Delta P O W}$ の音響特徵量を用いて転倒音及び非転倒音の 2 クラス識別を行った. 2 クラス 識別法はSVM（Support Vector Machine）と k-NN（k-Nearest Neighbor）とし，SVM のカーネル関数はガウスカー ネルを用いることにした（Boser et al. 1992）（Dasarathy, 1991）. SVM はサポートベクタを求め超境界面でクラス の識別，一方で k-NN では近傍データの属するクラスを多数決で識別を行うものである. $R_{\Delta P o w}$ は高周波数域と 低周波数域の境界付ける間值は，4.2 の結果より $200 \mathrm{~Hz}$ とした．評価セットは特定環境条件下であるデータセッ ト1（Dataset 1）及び不特定環境条件下であるデータセット2（Dataset 2）とし，各パラメータは対象となる各デ 一タセット空間に対して最小值を 0 また最大值を 1 として正規化を行った.

まず, パワーと $R_{\Delta P o w}$ におけるパラメータの空間分布について確認する. 図 10(a)及び(b)に零交差数とパワー $R_{\Delta P o w}$ を用いたときのパラメータの空間分布を示す， 図 10(a)は零交差数とパワー, 図 10(b)は零交差数と $R_{\Delta P o w}$ の結果 である．各結果から確認できるように，パワーでは転倒音と非転倒音の分布にオーバーラップが確認できるが, $R_{A P O W}$ では転倒音と非転倒音のパラメータ分布が完全に分離できることが確認できる．特に, 図 $10(\mathrm{~b})$ は不特定環 境条件下のデータセット 2 も対象にしていることから， $R_{\Delta P o w}$ を用いることで不特定環境条件環境下でも頑健な転 倒識別が期待できる. 加えて, 図 10(c)にSVM を用いたときのパラメータ分布を示す. SVM ではサポートベクタ を用いて実線で示される超平面が推定されていることが確認できる．各データは転倒音及び非転倒であるかは既 に分かっているので，各方法で識別した結果の正解及び不正解を検証することにする.

表 2 に交差検証を用いた正解及び不正解を基準とした 2 クラス識別の識別率を示す（Kohavi, 1995). 2 クラス 識別とは転倒と非転倒のクラスを意味する．まず，零交差数とパワー（Zcross+Pow）を対象に特定環境条件であ るデータセット 1（Dataset 1）に対する識別性能について確認する．表 2 より，SVM において 69.83\%，3-NN に おいて 68.97 \%であった。 これは図 10(a)から確認できるように，パワーではパラメータにおける分布のオーバー ラップが確認できるため, 妥当な識別性能であることいえる. 次に, 零交差数と $R_{\Delta P o w}\left(\mathrm{Zcross}+R_{\Delta P O W}\right)$ を対象に 両データセットに対する識別性能について確認する。特定環境条件下では SVM において 94.02 \%, 3-NN におい て $94.87 \%$ \%゙あった。 また，不特定環境条件下では SVMにおいては $90.48 \%$ ，3-NN においては $96.83 \%$ の識別性 能を確認した. 両セットともに, SVM では超平面の近傍にデータが存在するため $90 \%$ 程度の識別性能に留まっ た. 一方で, $\mathrm{k}-\mathrm{NN}$ では最小である $\mathrm{k}=3$ のときに最も良い識別性能が得られた. これは十分な空間分離ができて いたため, 低次であるほど高性能な結果となった，以上の結果から，零交差数と $R_{\Delta P o w}$ を用いることで不特定環 境条件下でも頑健に転倒識別ができる. 


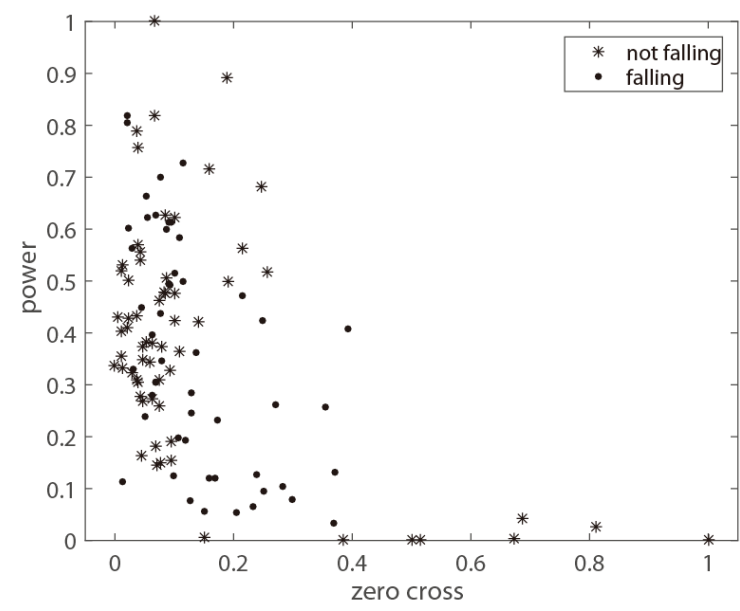

(a) k-NN (Zcross-Pow, Dataset 1).

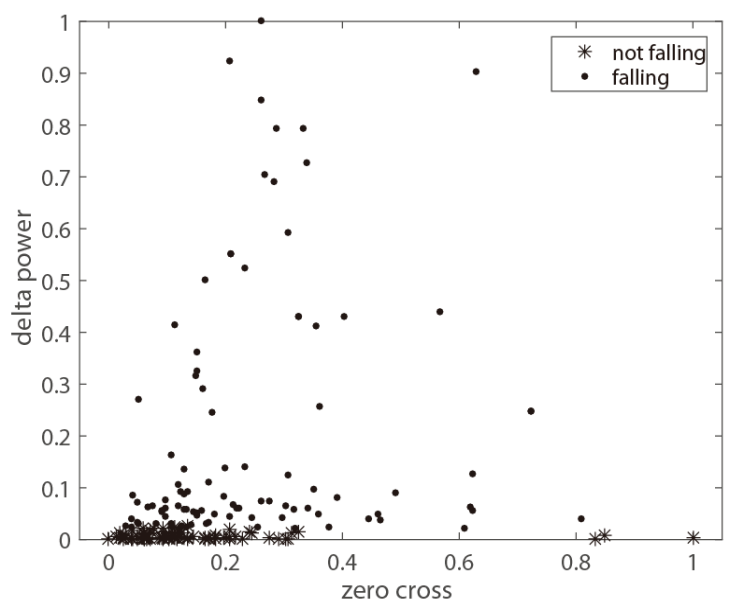

(b) k-NN (Zcross- $\triangle$ Pow, Dataset 1 \& 2).

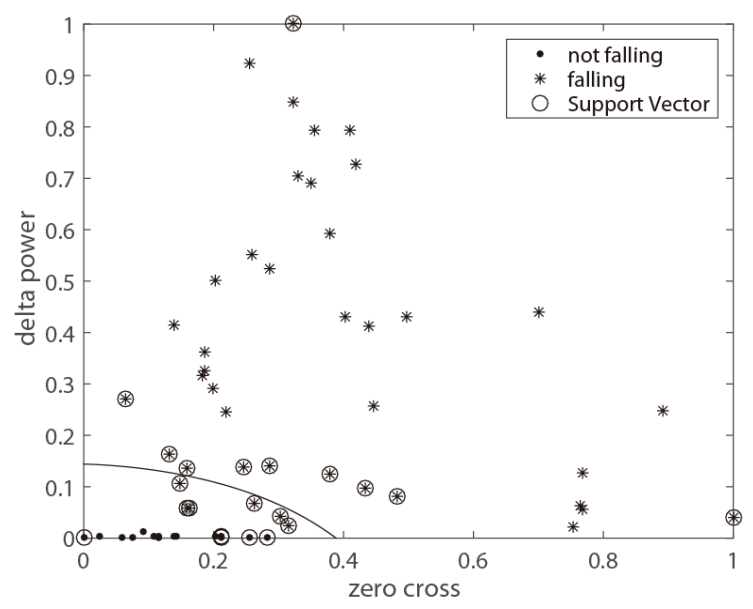

(c) SVM (Zcross- $\triangle$ Pow, Dataset 2).

Fig. 10 Parameter distribution of two-class discrimination using Zero cross and Pow / $R_{\triangle P o w}$.

Table 2 Two-class discrimination conditioned with cross-validation.

\begin{tabular}{|c|c|c|c|c|}
\hline \multirow{2}{*}{\multicolumn{2}{|c|}{$\frac{\text { Parameter }}{\text { Dataset }}$}} & \multirow{2}{*}{$\frac{\text { Zcross }+ \text { Pow }}{\text { Dataset } 1[\%]}$} & \multicolumn{2}{|c|}{ Zcross $+R_{\triangle P o w}$} \\
\hline & & & Dataset $1[\%]$ & Dataset $2[\%]$ \\
\hline & & 69.83 & 94.02 & 90.48 \\
\hline \multirow{5}{*}{$\mathrm{k}-\mathrm{NN}$} & $\mathrm{k}=3$ & 68.97 & 94.87 & 96.83 \\
\hline & $\mathrm{k}=5$ & 67.24 & 93.16 & 93.65 \\
\hline & $\mathrm{k}=7$ & 66.38 & 93.16 & 93.65 \\
\hline & $\mathrm{k}=9$ & 62.93 & 94.02 & 90.48 \\
\hline & $\mathrm{k}=11$ & 60.34 & 94.02 & 93.65 \\
\hline
\end{tabular}

\section{5. おわりに}

本研究ではプライバシーの担保が期待できる音情報を用いた転倒識別に関する研究行った。転倒音及び非転倒 音に対してウェーブレット解析を行ったところ，ヒトの転倒音おいて特有のスペクトル重心を捉えられることを 確認した. しかしながら, 転倒認識に必要なテンプレートやモデル推定が困難な点などから, 不特定環境条件下 でも頑健な転倒識別が求められる. そこで, パワーを動的特徵に拡張した $A$ Pow を用いることにした. このとき, 
$\triangle P o w$ とヒトの転倒時に生じるスペクトル重心に注目した音響特徵量 $R_{\Delta P o w}$ を提案し，不特定環境条件下でも頑健 な転倒識別の検討を行った. 以下に得られた知見を示す.

・転倒音と非転倒音のスペクトル重心に違いが確認できるため, このスペクトル重心に注目したバンドバスフ イルタと零交差数で転倒識別に有用な音響特徵量を得ることができる.

- 被験者, 床面条件, 転倒パターンなどの転倒条件でパワーに変動や影響が生じるため, 単純なパワーではな く動的特徴である $\triangle P O W$ を用いた音響特徴量 $R_{\triangle P O W}$ で頑健な特徵抽出ができる.

- 不特定環境条件下のデータベースを用いて転倒音と非転倒音を区別するスペクトル重心の閾值と $R_{\Delta P o w}$ のみ で 96.83\%の識別性能を得ることができる.

今後は，より頑健な識別を行うための音響特徵量の高度化や，実システムとしての実装また実時間処理の検討 を行う. 加えて, 発声や生活音などで所望転倒音がマスクされた際の影響や，より条件の厳しい不特定環境条件 下での検討も予定である.

\section{文献}

Bendary, N. E., Tan, Q., Pivot, F. C. and Lan, A., Fall detection and prevention for the elderly: a review of trends and challenges, International Journal on Smart Sensing and Intelligent Systems, Vol. 6, No. 3 (2013), paper 23.

Boser, B. E., Guyon, I. M. and Vapnik, V. N., A training algorithm for optimal margin classifiers, Proceedings of the fifth annual workshop on Computational learning theory (COLT '92) (1992), pp.144-152.

Dasarathy, B. V., Nearest Neighbor (NN) Norms: NN Pattern Classification Techniques, IEEE Computer Society Press (1991), p. 447.

土井元紀，井上博司，青木優太朗，大城理，人物追跡と転倒検知による独居高齢者遠隔見守りシステム，電気学 会論文誌 E, Vol. 126 No.8 (2006), pp.457-463.

Furui, S., Speaker-independent isolated word recognition using dynamic features of speech spectrum, IEEE Transactions on Acoustics, Speech and Signal Processing, Vol. ASSP-43, No. 1 (1986), pp.52-59.

Gouyon, F., Pachet, F. and Delerue, O., On the use of zero-crossing rate for an application of classification of percussive sounds, Proceedings of the COST G-6 Conference on Digital Audio Effects (2000), pp.DAFX-1 to DAFX-6.

Grey, J. M. and Gordon, J. W., Perceptual effects of spectral modifications on musical timbres, Journal of Acoustic Society of America, Vol. 63 No. 5 (1978), pp.1493-1500.

Grossman, A. and Morlet, J., Decomposition of Hardly functions into square integrable wavelets of constant shape, Society for Industrial and Applied Mathematics, Journal of Mathematical Analysis and Applications, Vol. 15 No. 4 (1984), pp.723-736.

池田浩太郎，転倒音による転倒検知，平成 25 年度法政大学大学院デザイン工学研究科紀要, Vol.2 (2013).

石光俊介, 坂野史歩, 中西良太, 中山仁史, 空田卓也, 前田夕貴, 転倒検知装置及び転倒判定方法, 特願 2016-31648 (2016).

金井浩，音・振動のスペクトル解析，コロナ社 (1999).

Khan, M. S., Yu, M., Feng, P., Wang, L. and Chambers, J., An unsupervised acoustic fall detection system using source separation for sound interference suppression, Signal Processing, Vol. 110 (2015), pp. 199-210.

Kohavi, R., A study of cross-validation and bootstrap for accuracy estimation and model selection, Proceedings of the International Joint Conference on Artificial Intelligence (IJCAI) (1995), pp.1137-1145.

株式会社 Libero, 高齢者安否確認システム, available from <http://www.anzentaisaku.com/anpikakunin/index.htm> (2008)（参照日 2016年 2 月 29 日）.

総務省統計局, 人口推移, 平成 27 年 4 月, available from <http://www.stat.go.jp/data/jinsui/2014np/> (2015) (参照日 2016 年 2 月 2 日).

西宏之，金金，木村義政，柿木稔男，音情報を用いたお年寄り見守りシステムの検討，電子情報通信学会技術報 告, Vol. 113, No. 381 (2014), LOIS2013-53(ICM2013-49), pp. 81-84.

株式会社ラムロック，ラムロックシステム，available from <http://www.ramrock.co.jp/ramrocksys/> (2011) (参照日 2016 年 2 月 29 日）。

品川佳満, 谷川智宏, 太田茂, 加速度センサを用いた人間の歩行・転倒の検出, 川崎医療福祉学会誌, Vol.9 (1999), pp.243-250.

The World Bank, Population ages 65 and above ( $\%$ of total), available from $<$ http://data.worldbank.org/indicator/SP.POP.65UP.TO.ZS > (2015)（参照日 2016 年 2 月 2 日）。 


\section{References}

Bendary, N. E., Tan, Q., Pivot, F. C. and Lan, A., Fall detection and prevention for the elderly: a review of trends and challenges, International Journal on Smart Sensing and Intelligent Systems, Vol. 6, No. 3 (2013), paper 23.

Boser, B. E., Guyon, I. M. and Vapnik, V. N., A training algorithm for optimal margin classifiers, Proceedings of the fifth annual workshop on Computational learning theory (COLT '92) (1992), pp.144-152.

Dasarathy, B. V., Nearest Neighbor (NN) Norms: NN Pattern Classification Techniques, IEEE Computer Society Press (1991), p. 447.

Doi, G., Inoue, H., Inoue, H. and Oshiro, O., Video surveillance system for elderly person living alone by person tracking and fall detection, IEEJ Transactions on Sensors and Micromachines E, Vol. 126 No.8 (2006), pp.457-463 (in Japanese).

Furui, S., Speaker-independent isolated word recognition using dynamic features of speech spectrum, IEEE Transactions on Acoustics, Speech and Signal Processing, Vol. ASSP-43, No. 1 (1986), pp.52-59.

Gouyon, F., Pachet, F. and Delerue, O., On the use of zero-crossing rate for an application of classification of percussive sounds, Proceedings of the COST G-6 Conference on Digital Audio Effects (2000), pp.DAFX-1 to DAFX-6.

Grey, J. M. and Gordon, J. W., Perceptual effects of spectral modifications on musical timbres, Journal of Acoustic Society of America, Vol. 63 No. 5 (1978), pp.1493-1500.

Grossman, A. and Morlet, J., Decomposition of Hardly functions into square integrable wavelets of constant shape, Society for Industrial and Applied Mathematics, Journal of Mathematical Analysis and Applications, Vol. 15 No. 4 (1984), pp.723-736.

Ikeda, K., Falling detection by falling sound, The bulletin of the Graduate School, Housei University, Vol.2 (2013) (in Japanese).

Ishimitsu, S., Sakano, S., Nakanishi, R., Nakayama, M., Sorada, T. and Maeda, Y., Japanese Patent disclosure 2016-31648 (2016) (in Japanese).

Kanai, H., Spectrum analysis for sound and vibration, Coronasha (1999) (in Japanese).

Khan, M. S., Yu, M., Feng, P., Wang, L. and Chambers, J., An unsupervised acoustic fall detection system using source separation for sound interference suppression, Signal Processing, Vol. 110 (2015), pp. 199-210.

Kohavi, R., A study of cross-validation and bootstrap for accuracy estimation and model selection, Proceedings of the International Joint Conference on Artificial Intelligence (IJCAI) (1995), pp.1137-1145.

Libero, available from <http://www.anzentaisaku.com/anpikakunin/index.htm> (2008) (accessed on 29 February, 2016) (in Japanese).

Ministry of Internal Affairs and Communications Statistics Bureau, Population Trends at April 2015, available from < http://www.stat.go.jp/data/jinsui/2014np/> (2015) (accessed on 2 February, 2016) (in Japanese)

Nishi, H., Kin, K., Kimura, Y. and Kakinoki, T., A watching system for aged people using acoustic informations, IEICE Technical Report, Vol. 113, No. 381 (2014), LOIS2013-53(ICM2013-49), pp. 81-84 (in Japanese).

Ramrock, Ramrock system, available from <http://www.ramrock.co.jp/ramrocksys/> (2011) (accessed on 29 February, 2016) (in Japanese).

Shinagawa, Y., Tanigawa, T. and Ohta, S., Detection of Human Gait and Falling Using an Accelerometer, Kawasaki Journal of Medical Welfare, Vol. 9 (1999), pp.243-250 (in Japanese).

The World Bank, Population ages 65 and above ( $\%$ of total), available from $<$ http://data.worldbank.org/indicator/SP.POP.65UP.TO.ZS > (2015) (accessed on 2 February, 2016) 